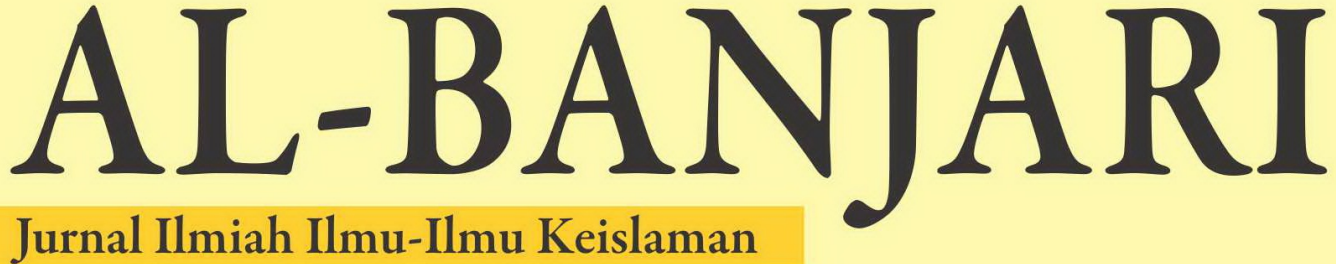

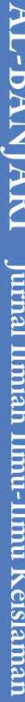

ISSN 1412-9507

Dialektika antara Filsafat dan Agama dalam Pemikiran Filsafat Islam: Kesinambungan dan Interaksi

Wardani

Masyarakat Islam Ideal dalam Konsepsi Filsafat Pendidikan Islam Andik Wahyun Muqoyyidin

Konflik Kelas dan Fenomena Komunisme dalam Hubungan

Struktural Menurut Pandangan Karl Marx Ahmad Syadzali

Ustadz Selebriti Abdullah Gymnastiar

(Perspektif Hipersemiotika Yasraf Amir Piliang)

Maskur

Pembaruan Islam di Kalimantan Selatan Pada Awal Abad Ke-20

Rahmadi

Deskripsi Kitab Senjata Mukmin Dan Risalah Doa

M. Adriani Yulizar dan Hamidi-Ilhami

Peta Gerakan Syi'ah di Kalimantan Selatan

Humaidy

\begin{tabular}{|c|c|c|c|c|c|}
\hline AL-BANJARI & Vol. 13 & $\begin{array}{c}\text { Halaman } \\
1-115\end{array}$ & No.1 & $\begin{array}{c}\text { Banjarmasin, } \\
\text { Januari - Juni 2014 }\end{array}$ & $\begin{array}{c}\text { ISSN } \\
1412-9507\end{array}$ \\
\hline
\end{tabular}




\section{AL - BANJARI}

Jurnal Ilmiah Ilmu-Ilmu Keislaman

Vol. 13, No. 1, Januari-Juni 2014

\section{DAFTAR ISI}

Dialektika antara Filsafat dan Agama dalam Pemikiran

Filsafat Islam: Kesinambungan dan Interaksi

Wardani

Masyarakat Islam Ideal dalam Konsepsi Filsafat Pendidikan Islam

Andik Wahyun Muqoyyidin

Konflik Kelas dan Fenomena Komunisme dalam Hubungan

Struktural Menurut Pandangan Karl Marx

Ahmad Syadzali

Ustadz Selebriti Abdullah Gymnastiar

(Perspektif Hipersemiotika Yasraf Amir Piliang)

Maskur

Pembaruan Islam di Kalimantan Selatan

Pada Awal Abad Ke-20

$49-65$

Rahmadi

Deskripsi Kitab Senjata Mukmin Dan Risalah Doa

66-94

M. Adriani Yulizar dan Hamidi Ilhami

Peta Gerakan Syi'ah di Kalimantan Selatan

Humaidy 


\title{
USTADZ SELEBRITI ABDULLAH GYMNASTIAR (Perspektif Hipersemiotika Yasraf Amir Piliang)
}

\author{
Maskur \\ Mahasiswa Akhlak dan Tasawuf Pascasarjana IAIN Antasari Banjarmasin
}

\begin{abstract}
The development of popular culture, particularly, in the development of information technology such as as television, mobile phones, and the Internet, have an impact on the creation of a new reality called hyperreality. Media, in this case, is able to reconstruct a new reality through the sophisticated technology. The construction of this medium also penetrates the religious area. This can be seen in the figure of Abdullah Gymnastiar (Aa Gym). Through the medium of information, Aa Gym is not only seen as a religious teacher who offers a depth of spirituality but also as a celebrity through the image formed. This paper aims to identify and describe the phenomenon of celebrity cleric/ ustadz Abdullah Gymnastiar in popular culture, using hyper-semiotics approach of Yasraf Amir Piliang. This paper attempts to explain the new reality of diversity of Abdullah Gymnastiar. Through the hyper-semiotics approach, religious hyper-reality form can be described scientifically.
\end{abstract}

Kata kunci: Abdullah Gymnastiar, hipersemiotika, Yasraf Amir Piliang, dan budaya populer

\section{Pendahuluan}

Perkembangan teknologi dan ilmu pengetahuan, termasuk di dalamnya perkembangan media dan ilmu-ilmu sosial kemanusiaan, yang begitu pesat secara relatif memperdekat jarak perbedaan budaya antara satu wilayah dengan wilayah yang lain. Hal demikian, pada gilirannya juga mempunyai pengaruh yang cukup besar terhadap kesadaran manusia tentang apa yang disebut fenomena agama. Agama untuk era sekarang tidak lagi dapat didekati dan dipahami hanya sebagai pendekatan teologis-normatif semata-mata. Perkembangan dunia yang semakin terbuka dan transparan, orang tidak dapat dipersalahkan untuk melihat fenomena agama secara aspektual, dimensional dan bahkan multi-dimensional approaches. ${ }^{1}$

${ }^{1}$ M. Amin Abdullah, Studi Agama : Normativitas atau Historisitas? (Yogyakarta: Pustaka Pelajar, 1999), h. 9. 
Salah satu penyebab mengapa keragaman masyarakat kontemporer berbeda dari apa yang pernah ada sebelumnya adalah "globalisasi." Menurut, Akbar S. Ahmed, globalisasi adalah "berbagai perkembangan dalam teknologi komunikasi, transportasi dan informasi yang membuat wilayah terjauh sekalipun dapat terjangkau." Alvin toffler menyebut perkembangan ini dengan "gelombang ketiga." Menurut Toffler, peradaban manusia telah bergerak melalui tiga tahapan gelombang yaitu gelombang pertanian, industri dan terakhir, informasi. Ketika memasuki era informasi yang ditandai oleh teknologi komunikasi dan informasi yang canggih, maka pertemuan dan benturan antara berbagai unsur yang berbeda dalam masyarakat akan semakin intensif. Dalam keadaan seperti ini, tak ada seorang pun yang dapat membendung serbuan pandangan-pandangan, nilai-nilai, hingga produk-produk yang tidak hanya berbeda bahkan saling bertentangan. ${ }^{2}$

Heidegger menjelaskan bahwa masyarakat kontemporer telah sampai pada satu jaman, yang di dalamnya eksistensi manusia tak lebih dari sebuah citraan ${ }^{3}$. Citraan itu sendiri menemukan bentuknya yang ironis, yang di dalamnya lebih diutamakan 'permainan bebas' tanda dan kode-kode ketimbang kebenaran, pesan dan makna-makna ideologis di balik citraan itu. ${ }^{4} \mathrm{Di}$ dalam artikelnya "The Age of the Word Picture”, Heidegger, sebagaimana yang dikutip Yasraf Amir Piliang, melihat dengan berkembang biaknya citraan-citraan di sekeliling kita, makna dunia tempat kita hidup berubah wujud menjadi tak lebih dari sebuah ontologi citraan. Teknologi citraan seperti televisi telah mengubah cara kita memandang dunia dan diri kita sendiri. Kini, seakan-akan televisi telah mengambil alih fungsi penglihatan kita, dan membentuk realitas dengan bahasanya sendiri. ${ }^{5}$

Umat manusia saat ini bisa dikatakan telah sampai pada sebuah penjelajahan global, sebuah petualangan jagat alam raya maya yang melampaui realitas (hiperrealitas). ${ }^{6}$ Baudrillard mendeskripsikan hiperrealitas sebagai suatu proses yang mengarah pada hancurnya batasan antara media dan dunia sosial, sehingga berita dan hiburan melebur satu sama lain dan 'TV menjadi dunia'. Televisi mensimulasikan situasi hidup nyata, dan tidak terlalu mempresentasikan dunia sebagaimana ia mengeksekusi dirinya sendiri. ${ }^{?}$

${ }^{2}$ Mujiburrahman, Mengindonesiakan Islam: Representasi dan Ideologi, (Yogyakarta: Pustaka Pelajar, 2008), h. 64-65.

${ }^{3}$ Citra (image) adalah sesuatu yang tampak oleh indera, akan tetapi tidak memiliki eksistensi substansial

4 Yasraf Amir Piliang, Hiper - Realitas Kebudayaan, (Yogyakarta: LKiS, 1999), h. 173.

5 Piliang, Dunia yang Dilipat: Tamasya Melampaui Batas-batas Kebudayaan, (Bandung: Matahari, 2011), h. 135.

6 Astar Hadi, Matinya Dunia Cyberspace: Kritik Humanis Mark Slouka terhadap Jagat Maya, (Yogyakarta: LKiS, 2005), h. 3.

7 Chris Barker, Cultural Stadies: Teori \& Praktik, (Yogyakarta: Kreasi Wacana, 2006), h. 299. 
Kondisi hiper-realitas tampak pula dalam kegiatan keagamaan. Media memegang peran sentral dalam membentuk opini masyarakat mengenai realitas kehidupan keagamaan yang ada. Seorang ustadz yang selama ini belum pernah diperhatikan, kemudian menjadi sosok selebriti terkenal, berdasarkan opini yang dibentuk media. Sementara dalam kesempatan lain, seorang tokoh agama tampil dalam sebuah acara hiburan. Musik ditampilkan bernuansa islami, sang ustadz selebriti menyampaikan beberapa hikmah kehidupan yang kira-kira memiliki hubungan dengan lagu yang diputar. Hakikatnya juga berdakwah, namun polanya yang sedikit berbeda. Dalam hal ini, tokoh tadi sudah menggunakan pola hiburan dalam dakwahnya. Ia ingin melakukan sesuatu yang tidak lagi dalam pola yang serius. $^{8}$

Da'i-da'i sukses senantiasa dibalas dengan sangat baik oleh komunitas-komunitas yang menghargai kemampuan mereka untuk mendidik dan memberi inspirasi kepada para muslim dalam hal-hal keimanan. Namun di Indonesia saat ini, da’i paling terkenal telah menjadi selebriti yang dijamu oleh media dan elit politik, serta oleh pengusaha-pengusaha cerdik yang menawarkan berbagai produk dan jasa yang secara serius dipasarkan. ${ }^{9}$ Salah satu da'i atau ustadz yang menjadi selebriti di Indonesia adalah Abdullah Gymnastiar (Aa Gym). Aa Gym sendiri telah menarik hati orangorang Indonesia dengan memasarkan pesan tentang Manajemen Qalbu melalui buku-buku, ceramah-ceramah yang disiarkan televisi nasional, dan seminar-seminar pelatihan Islam. Aa Gym sukses mengubah dirinya menjadi ikon kebajikan Islam, surbannya menjadi merek dagang dan Managemen Qalbu menjadi brand nasional sebagai salah satu konsumsi Islam. ${ }^{10}$

Kondisi yang terjadi di atas sebenarnya adalah perwujudan dari sebuah penggambaran Islam populer di media massa. Perkembangan teknologi informasi seperti televisi telah mengubah cara pandang masyarakat terhadap realitas keberagamaan. Media massa dalam hal ini mampu merekonstruksi realitas keberagamaan melalui citra yang dibentuk. Pekerjaan media pada hakikatnya adalah mengkonstruksi realitas. Isi media adalah hasil para pekerja media mengkonstruksikan berbagai realitas yang dipilihnya. Berger, dalam konteks ini, menjelaskan bahwa realitas sosial yang dialami manusia sehari-hari, dengan demikian, dikonstruksikan secara sosial (socially constructed). Menurut Berger, masyarakat itu sendiri, dengan berbagai institusinya, diciptakan dan dipertahankan atau diubah melalui tindakan dan interaksi manusia. ${ }^{11}$ Akibatnya, media massa mempunyai peluang yang sangat besar untuk mempengaruhi makna dan gambaran yang

8 Musnur Hery, "Islam Populer di Media Massa." Millah:Jurnal Studi Agama Vol. IX, No. 1 (Agustus2009), h. 115-116.

9 Greg Fealy \& Sally White, Ustadz Selebriti, Bisnis Moral \& Fatwa Online: Ragam Ekspresi Islam Kontemporer Indonesi, (Jakarta: Komunitas Bambu, 2012), h. 24.

10 Greg Fealy \& Sally White, Ustadz Selebriti, h. 89.

${ }^{11}$ Irfan Noor, Agama sebagai Universum Simbolik: Kajian Filosofis Pemikiran Peter L. Berger (Yogyakarta: Pustaka Prisma, 2011), h. 5. 
dihasilkan dari realitas yang dikonstruksikannya. setiap upaya "menceritakan" sebuah peristiwa, keadaan, benda, atau apa pun, pada hakikatnya adalah usaha mengkonstruksikan realitas, termasuk agama. ${ }^{12}$

Agama, termasuk Islam, mengandung simbol-simbol sistem sosio-kultural yang memberikan suatu konsepsi tentang realitas dan rancangan untuk mewujudkannya. Simbol-simbol tentang realitas ini tak selalu harus sama dengan realitas agama yang terwujud secara riil dalam kehidupan masyarakat, betapapun kuatnya yang terakhir ini dipengaruhi agama. ${ }^{13}$ Wacana ustadz selebriti merupakan satu bentuk nyata bagaimana simbol-simbol realitas keberagamaan kini tidak lagi dipahami hanya sebagai sesuatu yang sakral tetapi juga membentuk realitas baru yang lebih menghibur, tontonan, dan permukaan.

Barangkali tak banyak orang yang tahu apa di balik dari munculnya simbolsimbol keagamaan kontemporer pada era mutakhir sekarang ini. Maraknya simbol keagamaan tidak diiringi oleh tingkat kesadaran dan pemahaman terhadap simbol keagamaan tersebut. Sehingga terlihat indikasi bahwa masyarakat memang kurang memahami makna atau substansi dari simbol-simbol keagamaan yang dipakai. Padahal kalau dikaji secara mendalam terlihat bahwa ada indikasi yang kuat pada masyarakat akhir-akhir ini yang hanya menjadikan praktik dan pengalaman religius tak lebih sekedar komoditas hiburan atau komoditas belaka.

Perkembangan di dalam objek dan lingkup cultural studies $^{14}$ tersebut di atas tidak saja berlangsung ke arah yang yang lebih kompleks, akan tetapi juga dengan tempo perubahan yang semakin cepat. Kompleksitas dan kecepatan tempo perubahan objek kajian tersebut menuntut pula perubahan pada pendekatan yang digunakan di dalamnya. Di dalam menghadapi kompleksitas perubahan tersebut semiotika struktural tidak memadai lagi sebagai satu-satunya perangkat analisis kebudayaan. Perkembangan apa yang disebut sebagai semiotika post-strukturalis mungkin dapat mengisi ruang kosong yang ditinggalkan oleh semiotika struktural. ${ }^{15}$

\section{Metode}

Metode ini menggunakan metode kualitatif dengan pendekatan analisis hipersemiotika Yasraf Amir Piliang. Yasraf Amir Piliang merupakan salah satu tokoh intelektual, cendekiawan, dan pemikir tanah air yang menafsirkan konsep semiotika dari tokoh terdahulu dengan lebih ketat dan melontarkan kritik atau tafsir baru yang lebih segar yaitu konsep hipersemiotika. Hipersemiotika adalah ilmu tentang

\footnotetext{
${ }^{12}$ Alex Sobur, Analisis Teks Media: Suatu Pengantar untuk Analisis Wacana, Analisis Semiotika, dan Analisis Framing, (Bandung: PT. Remaja Rosdakarya, 2004), h. 88.

${ }^{13}$ Suyoto, dkk, Postmodernisme dan Masa Depan Peradaban, (Yogyakarta: Aditya Media, 1994), h. 147.

${ }^{14}$ Cultural studies merupakan kecendrungan dalam pemikiran yang mengombinasikan secara elektrik berbagai pendekatan dan metode analisis yang telah ada, seperti antropologi, semiotika, psikoanalisis, dan politik.

${ }^{15}$ Yasraf Amir Piliang, Semiotika dan Hipersemiotika: Gaya, Kode dan Matinya Makna, (Bandung: Matahari, 2012), h. 359.
} 
tanda dan fungsinya dalam masyarakat, yang secara khusus menyoroti sifat berlebihan atau ekses-ekses pada tanda, sistem tanda, dan proses pertandaan. ${ }^{16}$

Hipersemiotika sebagai sebuah metode, memiliki berbagai sifat, langkah dan prosedur yang dimiliki oleh metode semiotika umum, meskipun ada beberapa perbedaannya. Perbedaan mendasar adalah objek tanda itu sendiri. Metode hipersemiotika melingkupi hanya objek-objek tanda yang mengandung unsur melampaui, baik yang melampaui teks (intertekstualitas), melampaui struktur (dekonstruksi) dan melampaui realitas pada umumnya (bypersign). Tanda yang bersifat interteks, diperlukan data-data tanda asli yang dikutip dalam sebuah teks, untuk melihat kesalingbergantungan di antara mereka. Tanda yang bersifat dekonstruktif, diperlukan struktur asli tanda yang diruntuhkan melalui dekonstruksi, untuk melihat pelencengan, perluasan atau permainannya. Tanda hiper, diperlukan tanda-tanda tentang "realitas yang sebenarnya", untuk melihat muatan pemalsuan, penipuan, daur ulang, superlativitas, dan artifisialitas tanda. Metode ini mencoba menyingkap elemen-elemen anti struktur, anti kode, anti kemapanan atau anti realitas.

Hipersemiotika pada tingkat tanda merupakan upaya menyingkap elemenelemen penanda melampaui, yaitu tanda-tanda melampaui, baik dalam pengertian palsu, menipu, daur ulang, superlative atau artifisial. Ia juga dapat menyingkap elemen-elemen lintas semiotika, seperti tanda lintas waktu, tanda hibrid, tanda elektrik atau tanda sinkretik. Karena fenomena tanda di dalam hipersemiotika dicirikan oleh sifat-sifat yang dinamis, terus bergerak, melintas dan bertukar-tukar, maka kajian tentang aturan, konvensi, aturan main atau kode di dalam hipersemiotika tidak dapat lagi bertumpu pada pemahaman kode dalam semiotika struktural yang bersifat tetap, stabil, tak berubah dan mengikat.

Meskipun fokus perhatian dalam hipersemiotika adalah kajian hiper-kode, tetapi tidak berarti ia mengabaikan kajian makna. Kajian makna dan konotasi di dalam hipersemiotika lebih menekankan dinamika makna, yaitu bagaimana tanda dan makna bergerak, berubah, berpindah, bersilangan, bercampur, bermutasi, berkawin silang, bersimbiosis atau bahkan meniadakan dirinya sendiri. ${ }^{17}$

\section{Sign $\rightarrow$ denotation $\rightarrow$ hiper-signifier $\rightarrow$ hiper-code $\longrightarrow$ connotation}

Berdasarkan pemahaman di atas, prosedur dalam aplikasi pembacaan atau analisis tanda dalam hipersemiotika dapat dijelaskan sebagai berikut.

a. Melihat elemen-elemen pembangun tanda secara keseluruhan, baik dari segi penanda, materialis, teknik dan medianya.

b. Menyingkap elemen-elemen denotasi, yaitu bagaimana sebuah penanda menunjuk atau menggambarkan sebuah objek atau realitas diluar dirinya.

16 Piliang, Semiotika dan Hipersemiotika., h. 24-26.

17 Piliang, Semiotika dan Hipersemiotika, h. 294-297. 
c. Menyingkap elemen penanda hiper, yaitu elemen-elemen tanda yang melampaui teks, struktur, bentuk, kode dan realitas itu sendiri, dengan melihat relasinya dengan objek atau realitas yang dilampaui.

d. Membongkar kode hiper, yaitu kode-kode yang melampaui kode-kode yang baku, konvensional, tetap dan mengikat secara sosial.

e. Konotasi yang berkembang dalam konteks tanda yang melampaui konotasi-konotasi yang ada, baik secara sosial, politik, kultural maupun spiritual.

\section{Pembahasan}

Di awal tulisan ini sudah digambarkan sebuah ilustrasi bagaimana realitas keberagamaan mendapat bentuk baru dalam budaya populer. Bentuk baru tersebut dapat dilihat dalam wacana ustadz selebriti dalam budaya populer, dalam hal ini bagaimana media membentuk seorang Abdullah Gymnastiar, yang kemudian tidak lagi hanya dipahami sebagai seorang ustadz tetapi juga sebagai seorang idola lewat citra yang dibentuk. Pada pejelasan sebelumnya juga sudah dijelaskan tentang metode hipersemiotika Yasraf Amir Piliang yang penulis gunakan dalam pendekatan penelitian ini. Selanjutnya penulis akan memberikan uraian mengenai ustadz selebriti Abdullah Gymnastiar dalam budaya populer yang kemudian akan dianalisis menggunakan kajian hipersemiotika Yasraf Amir Piliang.

Agar dapat mencapai kepada hipersemiotika dalam menyoroti fenomena ustadz selebriti Abdullah Gymnastiar dalam budaya populer, perlu penulis tegaskan mengenai hipersemiotika. Penggunaan awalan hiper pada hiper-semiotika dengan sendirinya menekankan aspek-aspek melampaui atau berlebihan pada wacana semiotika. Hipersemiotika, dengan demikian, adalah sebuah ilmu tentang produksi tanda, yang melampaui realitas, yang berperan dalam membentuk dunia hiperrealitas. Dunia hiper-realitas, dalam hal ini, adalah dunia melampaui, yang tercipta akibat penggunaan hyper-signs dan sistem pertandaan yang melampaui (byper-signification). Oleh karena itu, hal-hal yang akan penulis uraikan hanya yang memiliki unsur hiper-nya saja. Hal ini dirasa penting untuk memberikan batasan agar tidak keluar jalur dari kajian hipersemiotika.

Istilah "ustadz selebriti" sendiri merupakan istilah yang dibangun dari relasi byper-signs tersebut yang mencerminkan hiperspritualitas. Hal yang tidak bisa dipungkiri dalam acara televisi, penceramah yang menjadi pusat perhatian dan Tuhan malah menempati tempat kedua. Sebagaimana seorang figur yang tampil ditelevisi, para ustadz ini diidolakan, ditunggu ceramahnya, dan penampilan dengan segenap ciri khas adalah hal yang digemari pemirsa. Lebih dari sekedar itu, figur ini sendiripun pada akhirnya menjadi bintang atau selebriti. Ini disadari oleh media di mana mereka menyadari ustadz sebagai selebriti atau bintang adalah komuditas yang menghasilkan keuntungan. Istilah ustadz selebriti disatu sisi menawarkan jalan bagi penceraban jiwe, pada sisi yang lain dapat menggiring pada perangkap gaya bidup (status, kelas, popularitas). 
Simbol-simbol keagamaan yang dibawa oleh ustadz "selebriti", ketika bercampur dengan budaya populer, maka simbol-simbol keagamaan tersebut akan dibangun oleh imajinasi populer sehingga menimbulkan makna-makna yang melampaui pada istilah hipersemiotika. Menurut Yasraf Amir Piliang, imajinasi populer yang dimaksud dibangun setidaknya ada empat bentuk, yaitu; cara berpikir populer, komunikasi populer, ritual populer, dan simbol populer.

\section{Hipersemiotika cara berpikir populer ustadz selebriti Abdullah Gymnastiar.}

Piliang menjelaskan yang yang dimaksud cara berpikir populer disini adalah cara berpikir jalan pintas yang penting mendapatkan kesenangan, kalau perlu tanpa berpikir. Sehingga umat yang terperangkap kedalam cara berpikir populer ini akan menjadikan umat malas berpikir, cari enak dan jalan pintas.

Perkembangan dakwah di era teknologi informasi digital menuntut inovasiinovasi produk keagamaan dalam penggunaan teknologi media digital. Lewat inovasi teknologi digital Aa Gym membuat terobosan dalam dakwahnya. Produk-produk dakwah seperti layanan-layanan pesan yang beragam melalui telepon genggam agar para pelanggan bisa menerima ceramah-ceramahnya, al-Qur'an seluler, dan keping DVD, dan lain sebagainya. Aa Gym begitu terampil dalam melakukan kreativitas populer dalam kemudahan dakwahnya, sehingga pemaknaan dakwah sebagai dakwah bil lisan sudah bergeser dengan berbagai kemudahan dari realitas virtual, yaitu realitas yang tercipta melalui perkembangan teknologi informasi digital.

Kreativitas Aa Gym dalam mengemas "cara berpikir populer" tak hanya sampai disitu saja. Baru-baru ini Aa Gym meluncurkan aplikasi 'Aa Gym Corner', sebuah terobosan baru dalam berdakwah dengan memanfaatkan gadget Apple. Aa Gym Corner sendiri merupakan aplikasi dakwah digital yang berisikan kumpulan bukubuku dan audiobook karya asli ustadz yang menggawangi Pondok Pesantren Daarut Tauhid ini. Aplikasi ini, dilengkapi dengan beberapa buku Aa Gym yang sebagian besar sudah terbit dalam bentuk buku cetak dan ditransformasi menjadi bentuk digital. Tak hanya buku, ada pula audiobook yang berisi rekaman dakwah Aa Gym dengan berbagai tema.

Pembacaan hipersemiotaka dapat dilihat dari tanda yang tidak lagi mengacu kepada realitas. Dakwah tidak lagi hanya dipahami sebagai dakwah bil lisan semata seperti tabligh akbar, ceramah agama, pengajian, malam tausiyah dan lain sebagainya. lewat kemajuan teknologi informasi digital dakwah telah menemukan bentuknya yang baru, yaitu realitas virtual. Tanda-tanda yang tercipta tidak lagi merlukan referensi realitas sebagai acuannya. Dakwah seluler, al-Qur'an seluler, serta kaset DVD Aa Gym tidak memerlukan lagi referensi realitas dalam artian bahwa produk tersebut dapat dinikmati kapan saja tanpa terikat dengan waktu, kondisi, realitas, sehingga menciptakan penanda yang terputus sama sekali dengan realitas. Hal inilah yang akhirnya menggiring kepada ketidakpastian makna sehingga sehingga melampaui kode-kode yang ada.

Melalui Aa Gym Corner tanda ditarik kedalam ekstrimitas tanda, yaitu tandatanda yang ditampilkan dalam sebuah pertandaan yang ekstrim. Hal ini dapat dilihat dalam Aa Gym Corner yang menyediakan berbagai layanan berupa buku- 
buku dan audiobook yang berisi rekaman dakwah dari Aa Gym dengan berbagai tema. Lewat teknologi efek peristiwa yang dihasilkan menjadi ekstrim, seperti efekefek kegairan membaca dan mendengarkan audiobook dan kecepatan dalam mengakses fitur. Dengan kecanggihan teknologi citraan terhadap efek pertandaan Aa Gym Corner menghasilkan makna yang jauh lebih besar, cepat, dan mudah.

Konotasi makna yang dihasilkan dari produk-produk dakwah Aa Gym adalah dakwah modern yang memiliki efek kuat, cepat, dan mudah dinikmati melalui pemanfaatan teknologi mutakhir, yang ditujukan kepada masyarat yang sibuk yang jarang mempunyai waktu luang. Bentuk-bentuk simulasi pertandaan dalam produk dakwah tersebut akhirnya membawa kepada kekaburan makna kearah realitas virtual. Pemaknaan tersebut akan terus berkembang seiring dengan perkembangan teknologi.

\section{Hipersemiotika komunikasi populer ustadz selebriti Abdullah Gymnastiar}

Wacana komunikasi populer mengarahkan dakwah keagamaan dihiasi dengan imajinasi dan fantasi-fantasi yang biasa hidup di dalam budaya populer, berupa bahasa, tindakan dan penampilan populer. Berbagai psikologi massa yang digunakan di dalam budaya populer, kini digunakan dalam wacana dakwah.

a. Komunikasi populer dalam Ceramah Aa Gym

Popularitas Aa Gym sebagai pendakwah telah membawa kepada tindak komunikasi populer, hal ini dapat dilihat dari komunikasi dakwah Aa Gym, dalam ceramahnya Aa Gym tidak banyak memuat ayat dan hadis, berbeda dengan para ulama atau para penceramah lainnya. Aa Gym melakukan dekonstruksi besar-besaran terhadap "narasi besar" mengenai apa yang disebut sebagai sosok ulama atau penceramah agama itu. Anggapan umum (narasi besar) selama ini yang ada dalam pikiran banyak orang adalah bahwa da'i adalah orang yang dalam setiap ceramahnya penuh bertaburan referensi ayat-ayat Al-Qur'an dan Hadis. Berbeda dengan hal tersebut, Aa Gym hanya berbicara tentang hati, karakter, dan keseharian manusia dengan penuturan yang sangat lugas dan sederhana dan hanya sedikit mengutip ayat maupun hadis.

Dekonstruksi terhadap apa yang disebut sebagai narasi besar itulah yang menimbulkan wacana hiper dimana sosok penceramah, da'i maupun ustadz sebagai tanda selalau dipahami sebagai orang yang dalam setiap ceramahnya menggunakan ayat dan hadis. Anggapan umum ini dipatahkan oleh Aa Gym melalui kebaruan pengucapan atau komunikasi dakwah sehingga melampaui kode yang ada (bypercode).

b. Komunikasi populer dalam Nasyid Aa Gym

Bicara tentang dakwah yang kreatif dan inovatif, Aa Gym merupakan salah satu contoh juru dakwah yang memanfaatkan seni musik sebagai bagian dari kreativitas dakwah populer. Piliang menyebut dakwah populer ini sebagai khutbah agama populer, yaitu dakwah yang menggunakan prinsip-prinsip hiburan populer sebagai bagian dari wacana komunikasi populer, salah satunya musik. Melalui musik nasyid Aa Gym dapat menyampaikan dakwah sekaligus dapat menghibur pendengarnya. 
Komunikasi populer di atas dapat dilihat sebagai hipersemiotika, dimana pesan dakwah tidak lagi hanya sebatas syiar agama saja tapi sudah di bentuk menjadi sebuah produk pengamasan populer, seperti hiburan dan tontonan. melalui pelibatan aneka tanda dan citra populer kehidupan keberagamaan menjadi bagian dari skema populer. Tanda hiper juga terlihat dari nasyid yang memadukan antara unsur dakwah dan syair islami serta instromen yang mengiringinya. Hal ini berarti terjadi pertukaran tanda-tanda, dimana dakwah yang memiliki unsur-unsur keagamaan dan musik sebagai bentuk hiburan kemudian dikawinsilangkan. Akibat dari hal ini adalah hibriditas agama, yaitu suatu kondisi percampuran antara sifat kesucian dan keduniaan, kemuliaan dan kedangkalan, ketinggian dan permukaan. Percampuran ini akhirnya menimbulkan bypercode yang ditimblkan dari kontradiksi dari kode yang ada, yaitu dakwah sebagai penyucian jiwa dan nasyid yang berisi musik yang menghibur.

Konotasi yang ditimbulkan dari dakwah melalui nasyid Aa Gym adalah dakwah hibrid yaitu dakwah yang menggabungkan antara bentuk-bentuk kesakralan agama dengan bentuk hiburan sehingga menimbulkan kontardiksi kultural agama, yaitu keagamaan yang memiliki sifat permukaan dan menghibur.

\section{Hipersemiotika ritualitas populer ustadz selebriti Abdullah Gymnastiar}

Menurut Yasraf Amir Piliang ritual populer macam ini berbeda dengan ritualritual keagamaan pada umumnya seperti puasa, sembahyang, zakat dan haji. Ia secara massif dilaksanakan berdasarkan paradigma budaya populer, terutama ketika semuanya menjadi bagian dari bentuk komuditas. Pelaksanaan ritual secara sistematis diorganisasikan dengan menggunakan logika komuditas dalam produksinya. Beberapa bentuk ritual diklasifikasikan dan disegmentasikan berdasarkan pada kelas sosial atau gaya hidup yang ada. Semuanya ditata dengan cara tertentu berdasarkan prinsip perbedaan sosial sebagaimana umumnya digunakan di dalam dunia gaya hidup konsumerisme.

Sebagai sistem tanda dakwah Aa Gym di simbolkan dengan tulisan "MQ" sebagai ikon, yang menanda'i dakwah Islam Aa Gym. Pada tingkat petanda MQ memberikan makna syiar agama dengan konsentrasi kepada qolbu manusia. Pesan yang yang ingin disampaikan dari dakwah Aa Gym yaitu "upaya sadar" untuk mempengaruhi dan mengajak orang lain, atau kelompok tertentu, agar mau mengikuti "jalan kebenaran" dengan pembersihan hati dengan melaksanakan ritual Islam.

Perkembangan arus teknologi dan informasi cendrung mengubah pemaknaan tanda-tanda tersebut. MQ sebagai ikonik dakwah Aa Gym pun dikemas dengan apik melalui teknologi media. Tanda-tanda cendrung berkembang hampir tanpa batas. MQ kini tak hanya tampil sebagai media dakwah tapi sudah menjadi brand di pasar nasional, seperti buku-buku berlebel MQ, Tabloid MQ, TVMQ, Radio MQ, Keping DVD dan lain sebagainya.

Masuknya dakwah MQ Aa Gym dalam budaya populer seperti dalam bukubuku, televisi, radio dan sebagainya telah membawa kepada keterputusan antara 
tanda dan penanda sehingga menumbulkan makna yang beragam. Dakwah MQ Aa Gym di satu sisi merupakan media atau ruang tempat memperoleh nilai-nilai spritualitas, pada sisi yang lain ia justru menggiring pada perangkap gaya hidup konsumtif.

Konotasi yang didapat dari dakwah MQ adalah orientasi perbaikan akhlak yang dilakukan lewat pengembangan konsep Manajemen Qolbu yang modern yaitu dengan cara penyampaian melalui percetakan, keeping DVD, pertelevisian, radio dan sebagainya yang berujung pada ritual komersialisasi.

\section{Hipersemiotika simbol populer ustadz selebriti Abdullah Gymnastiar}

Simbol populer atau penampilan populer yang mencakup mulai dari pakaian sampai rambut dan aksesoris yang menkankan efek-efek kesenangan, simbol, status, tema, prestise, daya pesona dan lain sebagainya. Hal itu dihadirkan sematamata untuk menarik perhatian, pesona, dan hasrat libido. Menariknya, fenomena penampilan populer itu memperlihatkan dua kecendrungan di dalam tubuh masyarakat Islam. Pertama, menjadi pengikut atau imitator dari model penampilan para elite agama. Kedua, pengombinasian penampilan bernafaskan religius dengan penampilan gaya hidup keduniaan.

Umumnya seorang da'i memakai baju takwa, sarung yang dilengkapi millineris kopiah atau songko dan sandal. Sedangkan Aa Gym selain berbusana seperti disebutkan tadi, pada kesempatan-kesempatan tertentu memakai busana lain, seperti jas atau suit, $t$-shirt berkerah turtleneck berlengan panjang, sarung atau dapat pula memakai pantalon yang dilengkapi millineris sorban dan sepatu atau sandal.

Pakaian di dalam Islam sebagai satu tanda harus bersandar pada sistem tanda pada tingkat ideologis, berlandaskan konvensi dan kode tertinggi (kesopanan, kepatuhan), dan ini harus tercermin pada pertandaan. Akan tetapi, proses penafsiran pakaian sebagai satu sistem bahasa pada tingkat yang lebih rendah, misalnya dikaitkan dengan konteks musim, tren, mode dapat dilakukan melalui proses dekonstruksi secara bebas dari makna yang konvensional; melalui permainan dekonstruksi dan signifiance bentuk, warna, motif yang kreatif, selama ia tidak bertentangan dengan kode ideologis.

Hal yang sama dapat dilihat pada tata busana yang dikenakan Aa Gym pada gambar di atas. Dalam kegiatan tertentu dapat dilihat bahwa busana Aa Gym mendekonstruksi tanda, bentuk, ekspresi bahkan kode-kode fabshion yang ada sebelumnya, seperti pengkombinasian pakaian resmi terlihat dari jas yang digunakan dan juga pakaian yang bernuansa Islami seperti sarung, peci dan sorban.

Dikaitkan dengan dua tingkatan pertandaan yang dikemukakan diatas, maka sistem pertandaan dalam fashion Aa Gym dapat digambarkan sebagai berikut:

\begin{tabular}{|c|c|c|c|}
\hline \multirow[b]{2}{*}{ Ideologi } & $\begin{array}{c}\text { Penanda } 1 \\
\text { Pakaian }\end{array}$ & $\begin{array}{l}\text { Petanda } 1 \\
\text { Elegan, dst }\end{array}$ & \\
\hline & \multicolumn{2}{|c|}{$\begin{array}{c}\text { Tanda } 1 \\
\text { Penanda } 2\end{array}$} & $\begin{array}{c}\text { Petanda } 2 \\
\text { Kesalehan, dst }\end{array}$ \\
\hline
\end{tabular}


Konsepnya adalah, bahwa merubah tanda melalui pilihan-pilihan dan kombinasi bentuk menghasilkan keragaman makna hangat, elegan, jiwa muda dan seterusnya, tetapi dengan tidak menanggalkan makna kesalehan di dalamnya. Tandatanda tersebut akan terus berkembang seiring dengan perkembangan fashion dalam budaya populer. Konotasi yang diperoleh dari tata busana yang dipakai Aa Gym memiliki citra (image) selain bersifat religius dalam bertindak juga mengikuti selera zaman.

\section{Simpulan}

Perkembangan teknologi mutakhir dalam budaya populer telah semakin menggambarkan dan menegaskan apa yang telah diperkirakan Piliang selama ini sebagai postspritualitas dalam kajian hipersemiotika, yaitu era dimana di dalamnya pertandaan spritualitas hidup di dalam ruang kontradiksi kultural, dan menjadikan kontradiksi itu sebagai prinsip utama. Pada satu sisi, mesin-mesin semiotika (media, televisi, internet, fesyen, gaya hidup) merupakan ruang tempat nilai-nilai spritualitas itu dapat disemedikan, pada sisi lain, ia justru menjadi ruang pemalsuan, pendistorsian, dan penyelewengan. Kontradiksi ini menggiring kepada tanda-tanda yang bergerak dinamis mengikuti segala perubahan.

Hasil penelitian dengan analisis hipersemiotika Yasraf Amir Piliang ini memberikan uraian tentang bagaimana sekarang ini di Indonesia seorang ustadz tidak lagi hanya dipandang sebagai seorang pendakwah saja, melainkan, menjadi seorang selebriti yang diidolakan masyarakat. Fenomena ustadz selebriti inipun melekat pada ketokohan seorang Abdullah Gymnastiar, melalui media ustadz Abdullah Gymnastiar tidak hanya populer sebagai seorang ustadz tetapi juga sebagai seorang penyanyi, aktor, penulis buku dan sebagainya. Penelitian ini juga mengungkapkan beberapa fenomena hiper dalam ketokohan ustadz Abdullah Gymnastiar, antara lain; Pertama, hipersemiotika cara berpikir populer Abdullah Gymnastiar yang dapat dilihat dari produk-produk Aa Gym yang menawarkan kemudahan akses spritualitas lewat kecanggihan teknologi. Kedua, Hipersemiotika komunikasi populer Abdullah Gymnastiar memperlihatkan tanda hiper melalui kontradiksi antara spritualitas agama dan hiburan. Ketiga, Hipersemiotika ritualitas populer Abdullah Gymnastiar, yaitu pemanfaatan ritualitas keagamaan dalam bentuk komuditas. Keempat, hipersemiotika simbol populer Abdullah Gymnastiar, yaitu berupa pengkombinasian simbol-simbol kesalehan dengan gaya hidup.

\section{Daftar Pustaka}

Abdullah, M. Amin. Studi Agama : Normativitas atau Historisitas? Yogyakarta: Pustaka Pelajar, 1999.

Barker, Chris. Cultural Stadies: Teori \& Praktik. Yogyakarta: Kreasi Wacana, 2006.

Fealy, Greg, dan Sally White. Ustadz Selebriti, Bisnis Moral \& Fatwa Online: Ragam Ekspresi Islam Kontemporer Indonesia. Jakarta: Komunitas Bambu, 2012.

Hadi, Astar, Matinya Dunia Cyberspace: Kritik Humanis Mark Slouka terhadap Jagat Maya, Yogyakarta: LKiS, 2005. 
Hery, Musnur, "Islam Populer di Media Massa." Millah:Jurnal Studi Agama Vol. IX, No. 1, (Agustus 2009).

Mujiburrahman, Mengindonesiakan Islam: Representasi dan Ideologi. Yogyakarta: Pustaka Pelajar, 2008.

Noor, Irfan. Agama sebagai Universum Simbolik: Kajian Filosofis Pemikiran Peter L. Berger. Yogyakarta: Pustaka Prisma, 2011.

Piliang, Yasraf Amir. Dunia yang Dilipat: Tamasya Melampaui Batas-batas Kebudayaan, Bandung: Matahari. 2011

- Hiper - Realitas Kebudayaan. Yogyakarta: LKiS, 1999.

. Semiotika dan Hipersemiotika: Gaya, Kode dan Matinya Makna. Bandung: Matahari, 2012.

Sobur, Alex. Analisis Teks Media: Suatu Pengantar untuk Analisis Wacana, Analisis Semiotika, dan Analisis Framing. Bandung: PT. Remaja Rosdakarya, 2004.

Suyoto, dkk, Postmodernisme dan Masa Depan Peradaban, Yogyakarta: Aditya Media, 1994. 